\title{
Epoxy composites reinforced with natural fillers such as flax fiber and linseed cakes (Rapid communication)
}

\author{
Danuta Matykiewicz ${ }^{1)}$ *), Olga Mysiukiewicz ${ }^{1)}$ \\ DOI: dx.doi.org/10.14314/polimery.2020.11.11
}

\begin{abstract}
Epoxy composites reinforced with flax fabric and modified with waste filler in the form of linseed cakes (LC) were prepared. Thermomechanical properties using the DMTA (Dynamic Mechanical Thermal Analysis), thermal properties using the TGA (Thermogravimetry) method, flexural strength, Charpy impact strength, Shore hardness and density of the composites were tested. The addition of small amount ground linseed cakes improved the value of the composite storage modulus. The introduction of a large amount of waste additive reduced the impact strength of composites, without affecting their thermostability and hardness.
\end{abstract}

Keywords: epoxy resin, flax fibers, linseed cakes.

\section{Kompozyty epoksydowe wzmocnione naturalnymi napełniaczami, takimi jak włókno lniane i makuchy lniane}

Streszczenie: Otrzymano kompozyty epoksydowe wzmocnione tkaniną lnianą i modyfikowane napełniaczem w postaci odpadowych makuchów lnianych (LC). Metodą DMTA zbadano właściwości termomechaniczne, metodą TGA - właściwości termiczne, ponadto oceniono wytrzymałość na zginanie, udarność według Charpy’ego, twardość Shore’a i gęstość kompozytów. Dodatek niewielkich ilości mielonych makuchów lnianych wpłynął na zwiększenie modułu zachowawczego kompozytów, natomiast wprowadzenie dużej ich ilości spowodowało zmniejszenie udarności kompozytów, bez zmiany ich termostabilności i twardości.

Słowa kluczowe: żywica epoksydowa, włókna lniane, makuchy lniane.

The growing impact of plastic products on the development of human living standards is associated with the need to manage waste and design environmentally friendly composite materials [1-4]. To obtain polymer composites, natural fibers such as flax, jute and hemp are used in conjunction with coupling agents, powder fillers and other modifiers $[5,6]$. Due to the problem of recycling cured epoxy resins, the introduction of natural additives into them can reduce their negative impact on the environment [7]. Epoxy composites with natural fibers offer good mechanical properties and high durability. However, improving the durability and thermomechanical properties of these composites using a cheap production method is still a challenge for scientists [8-12]. Sathish et al. proved that addition of flax fiber and $\mathrm{SiC}$ filler significantly enhance the mechanical properties of the epoxy composites [13]. Kamaraj et al. described an increase in tensile and flexural strength epoxy compos-

\footnotetext{
1) Poznan University of Technology, Faculty of Mechanical Engineering, Institute of Materials Technology, Piotrowo 3, 61-138 Poznań, Poland.

*) Author for correspondence:

danuta.matykiewicz@put.poznan.pl
}

ites reinforced with flax fabric and modified with graphene [14]. Peanut oil cake-derived cellulose fiber was successfully used as reinforcement in epoxy flax composites in work [15]. Also, improvement in impact strength and hardness of the palm fiber reinforced epoxy composites filled with granite powder was reported by Ojha et al. [16]. Effect of agro-waste filler such as mustard cake addition on mechanical and tribological properties of grewia optiva fiber/epoxy composites was studied by Sikarwar et al. [17].

Flaxseed is one of the most significant oilseeds for industrial, food, feed and fiber applications [18]. Linseed cake (LC) is a by-product of linseed oil production that does not have a large-scale industrial use $[19,20]$. However, LC contains different compounds including rigid lignocellulosic particles, hydrophilic oligosaccharides, protein and natural oil [21], which can have a modifying influence on polymeric composites, i.e. addition of linseed cake causes an increase of crystallinity and elasticity of thermoplastic composites, as it was shown in our previous research [22].

It should be emphasized that the literature does not present the technology of production and testing of hybrid epoxy composites reinforced with flax fabric and 
a)

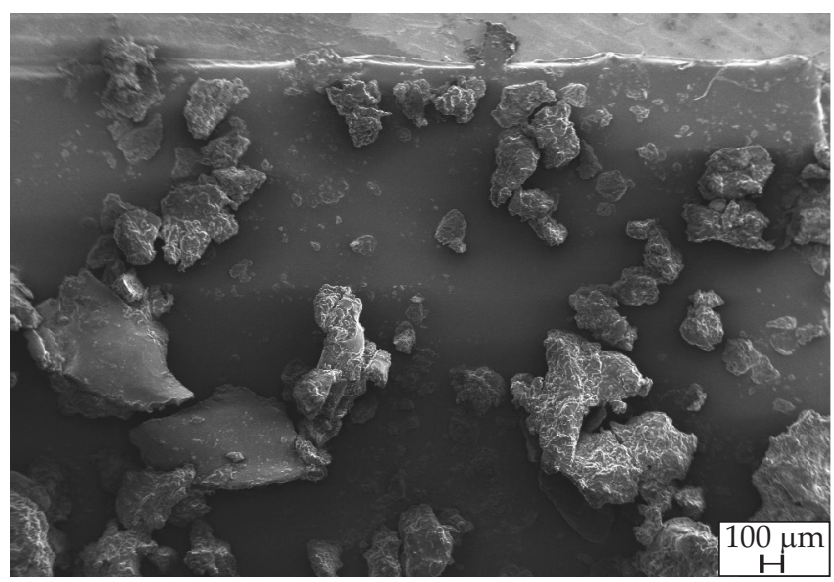

b)

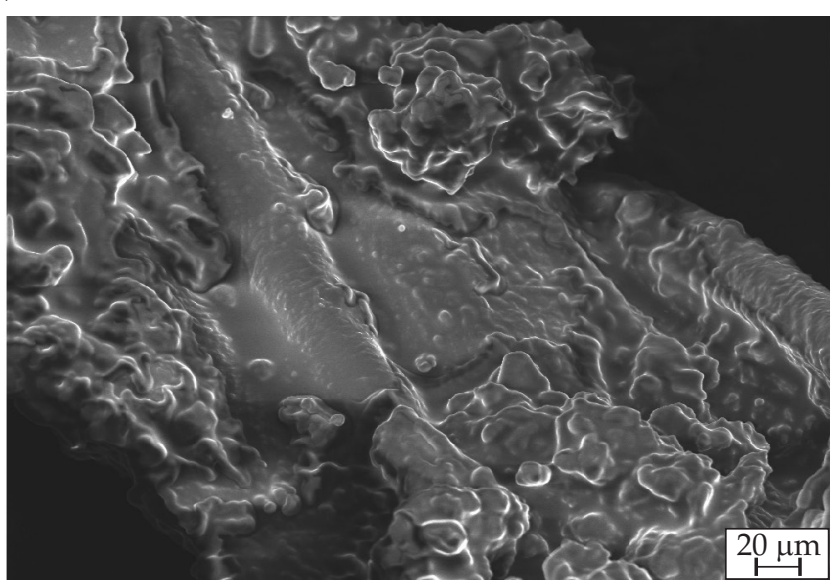

Fig. 1. SEM image of ground linseed cake particles, mag.: a) 100x, b) $1.00 \mathrm{k} \times$

modified with linseed cakes. Therefore, the aim of this article was to investigate the effect of linseed cakes on the thermomechanical properties of epoxy resin/flax fiber composites. Dynamic mechanical thermal analysis (DMTA), thermogravimetry (TGA), three-point bending test, Charpy impact test and Shore D hardness test were used to determine these properties.

\section{EXPERIMENTAL PART}

\section{Materials}

The subsequent constituents were used in the study: epoxy resin Epidian 6 based on bisphenol A (BPA) (epoxy number $0.510-0.540$, viscosity $10000-15000 \mathrm{mPa} \cdot \mathrm{s}$, density $1.16 \mathrm{~g} / \mathrm{cm}^{3}$ ), produced by CIECH (Poland), curing agent Z1 (triethylenetetramine), also produced by CIECH (Poland), flax fiber woven fabric type with $150 \mathrm{~g} / \mathrm{m}^{2}$ (Polski Len) and ground linseed cake LC (average particle size $800 \mu \mathrm{m}$, density of $1.27 \mathrm{~g} / \mathrm{cm}^{3}$ ). Figure 1 presents

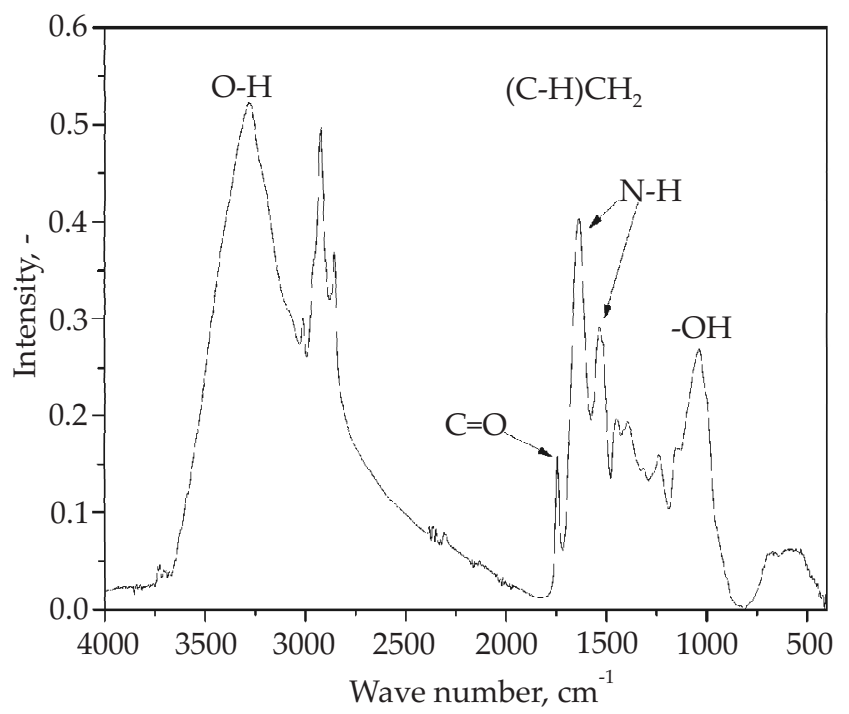

Fig. 2. FT-IR spectrum of ground linseed cake particles; the chemical groups assignment based on [22]
SEM image of ground linseed cake particles and Fig. 2 shows its chemical structure investigated by FT-IR ATR.

The spectroscopic measurements confirm the complex chemical build of LC. The notable peak around $3280 \mathrm{~cm}^{-1}$ comes from $\mathrm{O}-\mathrm{H}$ stretching bonds in the cellulose as well as the moisture absorbed by the filler, indicating the hydrophilic nature of LC. The peaks at $2920 \mathrm{~cm}^{-1}$ come from stretching of saturated fatty acids in the linseed oil present in the filler. The $1740 \mathrm{~cm}^{-1}$ also indicates presents of natural oil, i.e. its carbonyl ester compounds. The N-H bonds in the protein contained by the filler can be seen at $1630 \mathrm{~cm}^{-1}$ and $1540 \mathrm{~cm}^{-1}$. The peak at $1040 \mathrm{~cm}^{-1}$ also indicates presence of cellulose.

\section{Sample preparation}

Epoxy matrix was mixed with mechanical stirrer with $2.5,5,10 \mathrm{wt} \%$ of ground linseed cake respectively to the total weight at $1000 \mathrm{rpm} / 15 \mathrm{~min}$. Next the compositions were mixed with Z1 (13 parts Z1 per 100 parts epoxy monomer by weight) and degassed. The epoxy composites were fabricated in a mold using hand lay-up method, cured at ambient temperature $\left(20^{\circ} \mathrm{C}\right)$ for $24 \mathrm{~h}$ and postcured at $80^{\circ} \mathrm{C}$ for $3 \mathrm{~h}$. Composites contained 8 layers of flax fabric The samples were described as 0LC; $2.5 \mathrm{LC}$; 5LC; 10LC adequately to incorporated amount of ground linseed cake.

\section{Methods of testing}

The structure of the filler was monitored with Scanning Electron Microscopy (SEM). The filler surface were observed at the magnification of 100 and 1000 and digitally captured using a scanning electron microscope Zeiss Evo 40. The electron accelerating voltage of $12 \mathrm{kV}$ was used. Prior to the tests, all the specimens were sputtered with a layer of gold.

The chemical composition of the filler was evaluated using the Fourier Transform Infrared Spectroscopy (FT-IR) operating in the attenuated total reflection (ATR) 
$\mathrm{T}$ a b 1 e 1 . The values of composites storage modulus $G^{\prime}$, glass transitions $T g$, impact strength, hardness and density

\begin{tabular}{c|c|c|c|c|c|c|c}
\hline $\begin{array}{c}\text { Symbol of } \\
\text { sample }\end{array}$ & $\begin{array}{c}G^{\prime} \text { at } 25^{\circ} \mathrm{C} \\
\mathrm{MPa}\end{array}$ & $\begin{array}{c}\mathrm{G}^{\prime} \text { at } 125^{\circ} \mathrm{C} \\
\mathrm{MPa}\end{array}$ & $\begin{array}{c}\mathrm{Tg} \\
{ }^{\circ} \mathrm{C}\end{array}$ & $\begin{array}{c}\text { Tan } \delta \text { peak } \\
-\end{array}$ & $\begin{array}{c}\text { Impact } \\
\text { strength } \\
\mathrm{kJ} / \mathrm{m}^{2}\end{array}$ & $\begin{array}{c}\text { Shore D } \\
\text { hardness } \\
{ }^{\circ} \mathrm{Sh}\end{array}$ & $\begin{array}{c}\text { Density } \\
\mathrm{g} / \mathrm{cm}^{3}\end{array}$ \\
\hline 0LC & 1820 & 134 & 115 & 0.38 & $180 \pm 14$ & $83 \pm 1$ & $1.16 \pm 0.2$ \\
$2.5 \mathrm{LC}$ & 1990 & 158 & 120 & 0.36 & $145 \pm 12$ & $83 \pm 1$ & $1.14 \pm 0.1$ \\
5LC & 1560 & 68.5 & 110 & 0.42 & $102 \pm 13$ & $84 \pm 1$ & $1.13 \pm 0.2$ \\
10LC & 1570 & 87.4 & 119 & 0.42 & $58 \pm 8$ & $84 \pm 1$ & $1.14 \pm 0.3$ \\
\hline
\end{tabular}

mode. A Jasco FT/IR 4600 apparatus with an ATR Pro One attachment were used. A total of 128 scans with a resolution of $4 \mathrm{~cm}^{-1}$ were completed.

Thermal stability of the composites and the filler was assessed by the Thermogravimetric Analysis (TGA) under nitrogen and air atmosphere in the temperature range between $30^{\circ} \mathrm{C}$ and $900^{\circ} \mathrm{C}$ and a heating rate of $10^{\circ} \mathrm{C} / \mathrm{min}$ with the Netzsch TG 209 F1 apparatus. The initial decomposition temperature $75 \%$ was defined as the temperature at which the mass loss was $5 \%$. The residual mass $(W \%)$ was determined at $900^{\circ} \mathrm{C}$. Additionally, maximum thermal degradation temperatures were determined from Derivative Thermogravimetric (DTG) curves.

The dynamic-mechanical behaviors of the composites were evaluated by the DMTA method (Anton Paar MCR 301, Austria) in a torsion mode, at the frequency $1 \mathrm{~Hz}$ in the temperature range $25-180^{\circ} \mathrm{C}$, and at the heating rate $2^{\circ} \mathrm{C} / \mathrm{min}$. The glass transition temperature $(\mathrm{Tg})$ value was designated for maximum of $\tan \delta$ value.

Impact strength of the unnotched samples with $10 \times 4 \times 80\left(\mathrm{~mm}^{3}\right)$ size were measured by the Charpy method (ISO 179). The INSTRON Woolpert PW9 impact tester with $25 \mathrm{~J}$ hammer was used.

A three-point bending test of samples cut from composite sheets was carried out using a Zwick Roell Z010 testing machine in accordance with DIN EN ISO 14125 at a test speed of $1 \mathrm{~mm} / \mathrm{min}$ and with a $10 \mathrm{kN}$ load sensor. The span length was calculated as 16 times the sample thickness.

Shore D hardness was estimated using a Sauter HBD 100-0 (Germany), according to PN-EN ISO 868.

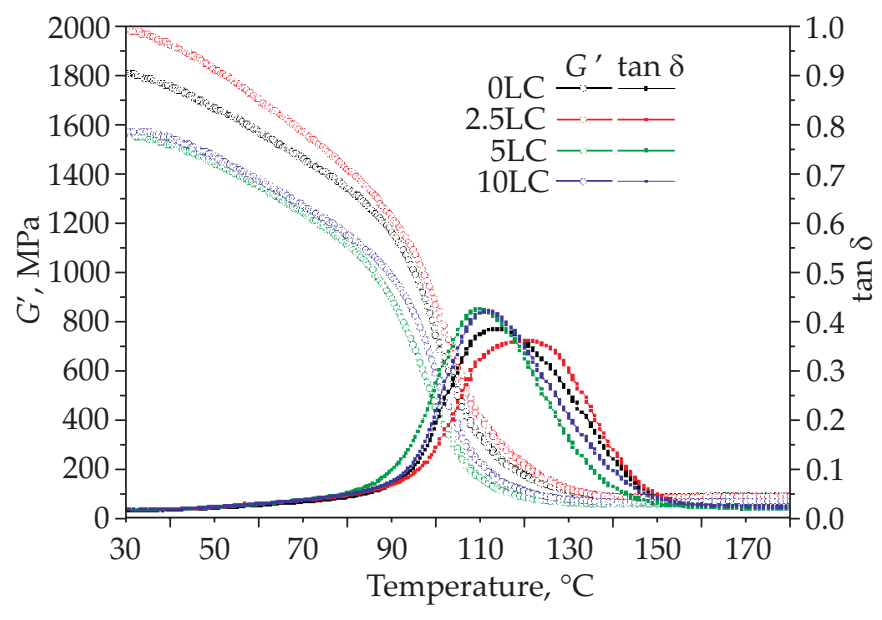

Fig. 3. The DMTA curves of the composites
The density of the composites was study based on PN-EN ISO 1183-1 standard by an immersion method using the AXIS AD 200 with in distilled water.

\section{RESULTS AND DISSCUSION}

The values of the storage modulus $G^{\prime}$, glass transition temperature $T g$ and $\tan \delta$ are summarized in Table 1.

The plots of the storage modulus $G^{\prime}$ and mechanical loss factor ( $\tan \delta$ ) versus temperature $(T)$ for the composites are shown in Fig. 3.

The storage modulus value was significantly lowered with increase of temperature and reached a rubbery plateau at high temperature [23]. Presence of LC natural particles may restrict mobility of the polymer matrix and act as micro reinforcement. The addition of linseed cakes increased the storage modulus $G^{\prime}$ (from $1820 \mathrm{MPa}$ to $1990 \mathrm{MPa}$ ) and the glass transition temperature (from $115^{\circ} \mathrm{C}$ to $120^{\circ} \mathrm{C}$ ) of the samples with $2.5 \mathrm{wt} \% \mathrm{LC}$. The incorporation of higher amount of ground linseed cakes (5 and 10 wt \%) decreases the $G^{\prime}$ and $T g$ values, which can be related to weak filler/epoxy matrix adhesion and agglomeration of filler. A similar tendency was observed in the impact strength values of the tested composites. The presence of a large volume of particles can cause crack propagation in the material and act as a notch (Table 1).

Three-point bending test results of the composites are presented in Fig. 4.

The flexural strength of tested materials was in the range of 89 to $108 \mathrm{MPa}$, and the value of the flexural modulus was from 3.4 to $4.2 \mathrm{GPa}$. As in the case of impact strength, the introduction of a small amount of waste filler did not significantly affect the flexural properties. On the other hand, adding a larger LC amount will reduce both flexural strength and modulus compared to reference samples. However, it should be emphasized that the introduction of LC into the epoxy matrix did not affect the value of hardness and density of composites.

The TG and DTG curves of the tested composites are shown in Fig. 5, and the data are collected in the Table 2.

A single-stage decomposition process was observed for all tested materials. Even though the decomposition of linseed cake begins at lower temperatures, it is caused by evaporation of moisture and no significant effect of the addition of the filler on the thermal stability of the tested materials was observed (Table 2). The thermal stability of 
a)

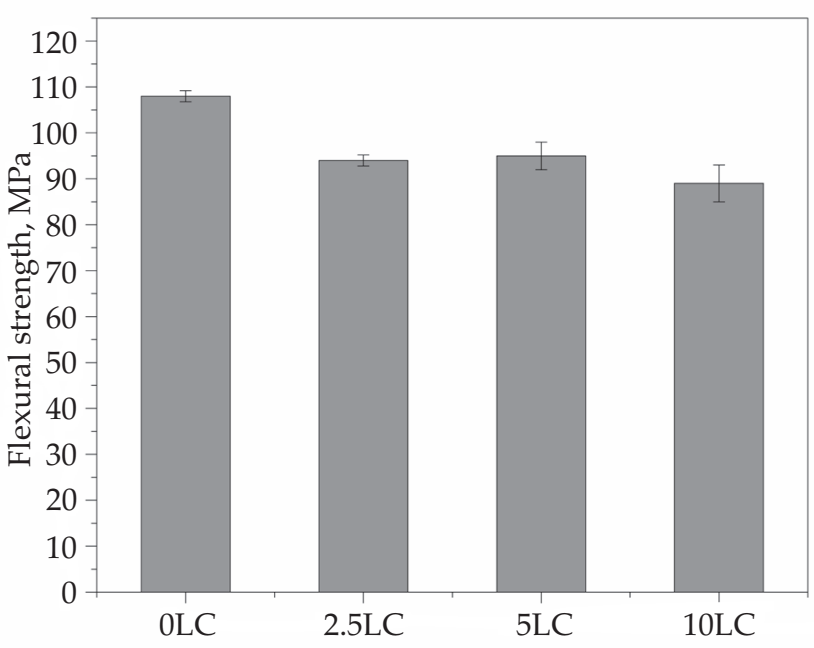

b)

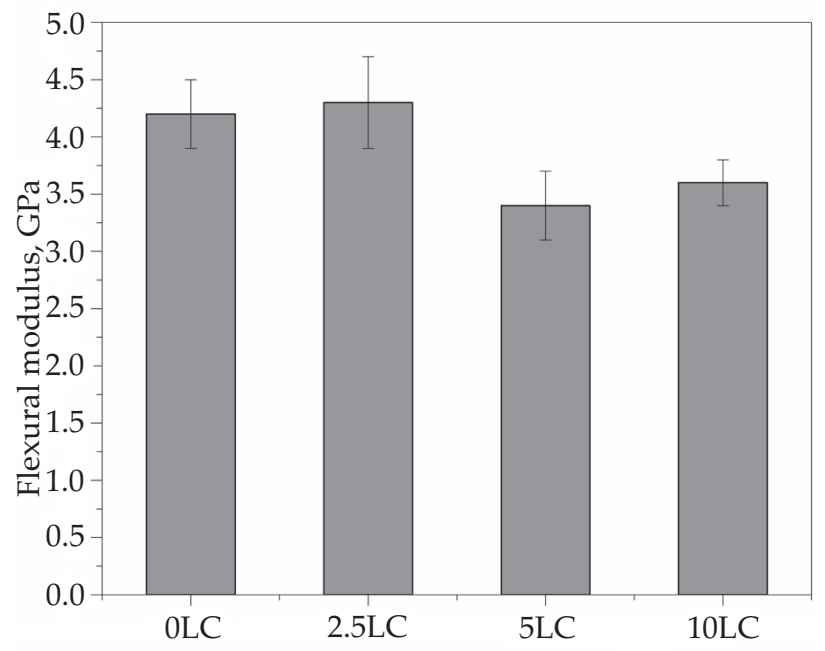

Fig. 4. Flexural: a) strength, b) modulus of the composites

T a b l e 2. The TGA and DTGA data of the composites investigated under nitrogen

\begin{tabular}{|c|c|c|c|}
\hline Material & $\begin{array}{l}\mathrm{T} 5 \% \\
{ }^{\circ} \mathrm{C}\end{array}$ & W\% & DTG \\
\hline OLC & 306.6 & 13.0 & $\begin{array}{c}361.0^{\circ} \mathrm{C} \\
-12.99 \% / \mathrm{min}\end{array}$ \\
\hline 2.5LC & 302.8 & 13.4 & $\begin{array}{c}362.8^{\circ} \mathrm{C} \\
-12.97 \% / \mathrm{min}\end{array}$ \\
\hline 5LC & 303.5 & 12.1 & $\begin{array}{c}363.5^{\circ} \mathrm{C} \\
-13.80 \% / \mathrm{min}\end{array}$ \\
\hline 10LC & 303.4 & 12.9 & $\begin{array}{c}358.4^{\circ} \mathrm{C} \\
-13.48 \% / \mathrm{min}\end{array}$ \\
\hline LC & 121.5 & 19.5 & $\begin{array}{c}309.5^{\circ} \mathrm{C} \\
-0.40 \% / \mathrm{min}\end{array}$ \\
\hline
\end{tabular}

composites modified with LC was averaged $303^{\circ} \mathrm{C}$, and the residual mass was about $13 \mathrm{wt} \%$. The introduction of a well-dispersed agro-waste filler may also improve thermal stability and delay degradation of the epoxy matrix [24]. The results obtained in the work are promising and

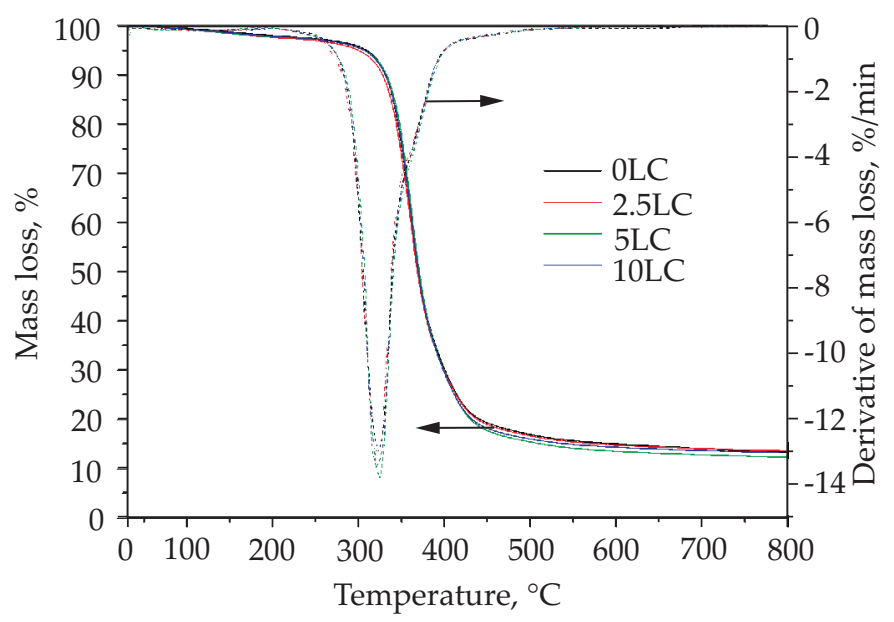

Fig. 5. TG and DTGA curves of the composites investigated under nitrogen may form the basis for developing a useful method of using waste filler in epoxy materials.

\section{CONCLUSIONS}

During application natural fillers as a reinforcement or low cost filler for polymer composites, the thermomechanical properties obtained depend mainly on their proper preparation and connection with the polymer matrix. The addition of ground linseed cake caused an increase in the value of the composite storage module for samples with a low LC content $(2.5 \mathrm{wt} \%)$. The introduction of linseed cake leads to a decrease in the impact strength of composites while increasing their rigidity and does not affect their thermal stability, hardness and density. Therefore, these composites can be used as environmentally friendly, thermally stable materials with high rigidity.

This research was funded by the Ministry of Science \& Higher Education in Poland under Project No 0613/SBAD/4630 and 02/25/DSMK/4545. 


\section{REFERENCES}

[1] Singh A.S., Halder S., Kumar A. et al.: Materials Chemistry and Physics 2020, 243, 122112. https://doi.org/10.1016/j.matchemphys.2019.122112

[2] Andrzejewski J., Barczewski M., Szostak M.: Polymers 2019, 11, 1881.

https://doi.org/10.3390/polym11111881

[3] Salasinska K., Mizera K., Barczewski M. et al.: Polymer Testing 2019, 79, 106036. https://doi.org/10.1016/j.polymertesting.2019.106036

[4] Andrzejewski J., Szostak M., Barczewski M. et al.: Composites Part B: Engineering 2019, 163, 655. https://doi.org/10.1016/j.compositesb.2018.12.109

[5] Matykiewicz D., Barczewski M., Mysiukiewicz O., Skórczewska K.: Journal of Natural Fibers 2019, 1-17. https://doi.org/10.1080/15440478.2019.1645792

[6] Mittal V., Saini R., Sinha S.: Composites Part B: Engineering 2016, 99, 425.

https://doi.org/10.1016/j.compositesb.2016.06.051

[7] Kim Y.N., Kim Y.O., Kim S.Y. et al.: Composites Science and Technology 2019, 173, 66. https://doi.org/10.1016/j.compscitech.2019.01.026

[8] Raju K., Balakrishnan M.: Materials Today: Proceedings 2020, 21, 52. https://doi.org/10.1016/j.matpr.2019.05.359

[9] Hallonet A., Ferrier E., Michel L. et al.: Construction and Building Materials 2019, 205, 679. https://doi.org/10.1016/j.conbuildmat.2019.02.040

[10] Salasinska K., Barczewski M., Borucka M. et al.: Polymers 2019, 11, 1234. https://doi.org/10.3390/polym11081234

[11] Santiago D., Guzmán D., Ramis X. et al.: Polymers 2020, 12 (1), 44. https://doi.org/10.3390/polym12010044
[12] Jia Y., Fiedler B.: Composites Communications 2020, 18, 5. https://doi.org/10.1016/j.coco.2019.12.010

[13] Sathish S., Kumaresan K., Prabhu L. et al.: Journal of Materials 2018, 48, 476.

[14] Kamaraj M., Dodson E.A., Datta S.: Advanced Composite Materials 2019. https://doi.org/10.1080/09243046.2019.1709679

[15] Ojha A.R., Biswal S.K.: Composites Communications 2019, 16, 158. https://doi.org/10.1016/j.coco.2019.10.003

[16] Sumesh K.R., Kanthavel K., Kavimani V.: International Journal of Biological Macromolecules 2020, 150, 775. https://doi.org/10.1016/j.ijbiomac.2020.02.118

[17] Sikarwar H.S., Goyal S., Kumar S. et al.: Asian Journal of Science and Technology 2018, 09 (09), 8610.

[18] Singh K.K, Mridula D., Rehal J. et al.: Critical Reviews in Food Science and Nutrition 2011, 51, 210. https://doi.org/10.1080/10408390903537241

[19] Mysiukiewicz O., Barczewski M., Skórczewska K. et al.: Polymers 2019, 11, 1495. https://doi.org/10.3390/polym11091495

[20] Pat. Appl. P 427460 (2018).

[21] Zuk M., Richter J., Matuła J. et al.: Industrial Crops and Products 2015, 75, 165-177. https://doi.org/10.1016/j.indcrop.2015.05.005

[22] Mysiukiewicz O., Barczewski M.: Journal of Applied Polymer Science 2019, 136, 47152. https://doi.org/10.1002/app.47152

[23] Emami Z., Meng Q., Pircheraghi G. et al.: Cellulose 2015, 22, 3161. https://doi.org/10.1007/s10570-015-0728-6

[24] Prabhakar M.N., Shah A.U.R., Rao K.C. et al.: Fibers and Polymers 2015, 16, 1119. https://doi.org/10.1007/s12221-015-1119-1

Received 27 IV 2020. 